\title{
Athenian Marital Life: A Union of Affection or of Duty?
}

\begin{abstract}
Since a treatise or some historical account committed to recording information on the ancient Athenian society is absent in Athenian historical sources, any information on ancient Athenian society needs to be configured based on analytical examination of evidence gathered from numerous sources facetted by logical conjectures. By cross examining literary, archaeological and iconographical evidence, the social historian can therefore develop and configure the ancient Athenian social structure in order to understand it better within its socio-political context. This paper therefore makes an attempt to understand Classical Athenian family and the atmosphere which conditioned it with the help of literary and iconographical evidence. The objective of the present study is to re-examine the literary evidence on a par with the iconographical evidence which produce domestic scenes in order to investigate whether any affection existed among Athenian spouses because the interpretations given to some such scenes seem problematic. The study is mainly based on library research with evidence from verse and prose literature, relevant oratorical texts, and images of Attic vase paintings extensively examined.
\end{abstract}

Key Words: Classical Athens; Marital relations; Affection; Duty; Literary, archaeological and iconographical representations. 
Athenian historical sources do not provide us with a treatise or some historical account committed to recording information on the ancient Athenian society. Any information on ancient Athenian society, therefore, needs to be configured based on analytical examination of evidence gathered from numerous sources facetted by logical conjectures. Accordingly, the social historians need to derive, construe or filter their information from various literary, archaeological, and iconographical sources. Thanks to the rich cultural and artistic maturity in Athens, which elevated her to the position of being the centre of Greek cultuxre during the classical period, she became the birth place of multifarious literary and artistic creations of high standard. These numerous creations refer to or bear information on their contemporary Athenian society, politics and culture as well as commerce. By cross examining literary, archaeological and iconographical evidence, one could develop and configure the ancient Athenian social structure in order to understand it better within its socio-political context. The present study attempts to understand the classical Athenian family and the atmosphere which conditioned it with the help of literary and iconographical evidence. In fact, a meticulous study incorporated with other supportive evidence may have the potential to discard even firmly established conceptions.

The objective of the present study is to re-examine the literary evidence on a par with the iconographical evidence which produce domestic scenes in order to perceive whether any affection existed among Athenian spouses because the interpretations given to some such scenes seem problematic. The study was carried out through library research. As for the evidence from primary sources, both verse and prose literature have been examined along with the relevant oratorical texts. Apart from this, images of Attic vase paintings were extensively examined as they appeared in primary sources such as Corpus Vasorum Antiquorum ${ }^{1}$ as well as in the secondary sources. Images published in electronic media, especially the Beazley archive maintained by the University of Oxford, were also used where necessary.

According to the generally accepted view, Athenians regarded their wives as essential tools which produce legitimate children while they looked to courtesans, prostitutes and hetaerae (respectable courtesans) for entertainment. It is also believed that the Athenians bore no sentiments of affection for their spouses. Such attitudes of cold sentiment between spouses have their basis in the ideologies expressed by normative writers such as Hesiod, ${ }^{2}$ Plato, Aristotle and Xenophon who propose a wide age gap between the spouses. ${ }^{3}$ Early marriage and limited social exposure at least for the upper-class women may have been a measure in place to assure the legitimacy of their offspring while late marriageable age for men may have been to enable them to become settled in their lives and to get trained as experienced citizens. Besides, Xenophon considered it a disgrace for a man to

\footnotetext{
${ }^{1}$ I had the opportunity to use several of these volumes in the Library of Art History in the University of Wisconsin, Madison, USA, as a Fulbright Research Scholar in 2009/2010. I am thankful to the library staff and the Dept. of Ancient History in that University for their support in this concern.

${ }^{2}$ Though Hesiod does not belong to the classical period, his epic poems were in the curriculum of Greek education along with the texts of Homer; thus they were well known among the Classical Greeks just in the same way their ideas were known in their contemporary times.

${ }^{3}$ Hes. WD 698 [bride 18, groom 30]; Pl. Laws 721b, 772d; Rep. 460eff. [groom 25 or over]; Arist. Pol. 1335a13-23 (7. 14, 6) [groom 37 or little before, bride at 18).; Xen. Oec.3.13, 7. 5-6 [bride 15], Mem. II. 2,4 [groom 30].
} 
spend time at home during the daytime. ${ }^{4}$ Such perceptions of the normative writers were further supported by man-made legislation which only showed concerns regarding the legitimacy of the offspring, the right to inherit property and citizenship rights (Harrison 25-26). ${ }^{5}$ There is no reference as such which induce or promote affection between spouses as marriage was seen as a contract between the male guardian (usually the father) of the potential bride and the spouse (or the father of the groom). In addition, not only was the bride expected to play a passive role (Harrison 5-6), the spouse of an epikleros was decided by the property she inherited (Harrison 11). ${ }^{6}$ Moreover, the law seemed to have allowed more power to the father (the original kyrios or guardian) of the bride over her husband (Harrison $31)$. The interpretation and explanation of many paintings in attic red and black figure vases are based on this perception.

E. C. Keuls too believes that marriage was a contract between a man and his wife, which brought no joy or satisfaction to the wife, and that marital relationship and sexual intercourse were governed by duty or obligation, not love or joy (Keuls 98-118). She also believes that Athenian households were strictly divided between the genders and that the husband and wife did not sleep together using a narrow couch for intercourse (Keuls 210-212). She bases her view on iconographical representations where large couches are not shown but only a narrow couch (kline). She further uses Eupheletos' description on the division of his house as reported in Lysias' speech on the murder of Eratosthenes in support of her point (Lys., 1.9-10). N. Massar (38) too finds no evidence for affection among the couples depicted in the scenes from the women's quarters (gynaikonitis) or in the departure of a warrior in Greek pottery. He however does not consider these representations to be realistic but fuelled from the imagination of the painter as he attempts to mix mythical themes with realistic themes as in the case of the representation showing Eriphile ${ }^{7}$ with her husband, child and attendant (Massar 27$38)$.

Yet, information from literary sources, specifically those from Athenian drama and law court speeches, suggest that the condition of Athenian families was not as stern and cold as preached and promoted by the normative writers such as Hesiod, Plato, Aristotle and Xenophon. ${ }^{8}$ This idea is further confirmed through many domestic scenes depicted in Athenian vases such as the following hydria ${ }^{9}$ unearthed from a cemetery near Vari in Attica [Ht. $34.6 \mathrm{~cm}$., dm.

\footnotetext{
${ }^{4}$ Xen. Oec. 4. 2-3; during the day women engaged in indoor activities: 9.2-10.13 while men were busy with outdoor activities: 10.2-11.23.

${ }^{5}$ This may have been the case at least after $451 / 0$ BC when Pericles demanded both parents to be Athenian citizens in order to be eligible to become an Athenian citizen. Harrison, A. R. W., The Law of Athens, vol. 1, new ed. London and Indiana, 1998, pp. 25-26.

${ }^{6}$ Epikleros was a female heir to her father's property. If a woman who was already married become an epikleros her nearest male relative could claim her hand and force the dissolution of her existing marriage. Harrison, 1998, p.11.

${ }^{7}$ Eriphile was a mythical character, wife of Amphiarus, their children were Alcmaeon, Amphilochus, Eurydice and Demonassa. Eriphile lured her husband to join the war against Thebes by using the necklace of Hermonia given to Eriphile by Polynices.

${ }^{8}$ For reference see foot note 3 .

${ }^{9}$ The mouth is lipped, and reserved above. Fillet between foot and body. The scene curves up over the shoulder, with a laurel wreath and berry pattern above, and meander with dotted-cross-square below. There is an egg pattern around the lip, and at the base of the handles. The space under the handles is reserved. But in here or in any other discussion on this vase there is no mention of the other side of the vase; thus, whether there is only this scene on this vase and the other side remains plain is hard to know: Robinson, D. M., Corpus Vasorum Antiquorum, United States of America, The Robinson Collection,
} 
$24.6 \mathrm{~cm}$.], datable to a time around 440 and $430 \mathrm{BC}$ and attributed to a follower of Polygnotos. ${ }^{10}$

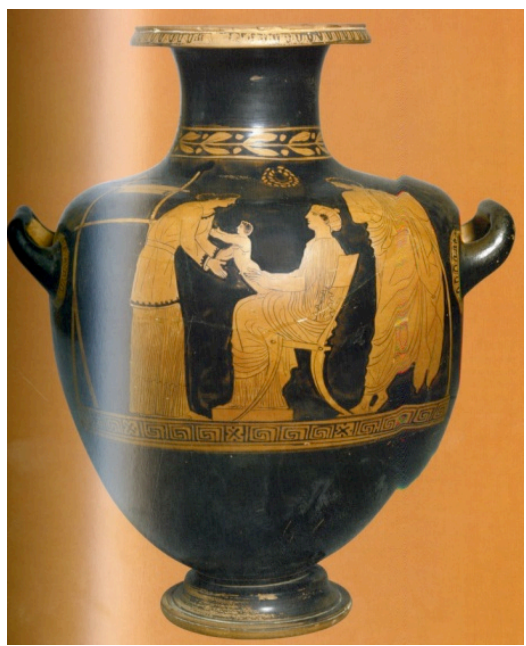

Fig.1: A family scene shown on a hydria vase (CVA Robinson plate 43$)^{11}$

The vase shows a domestic scene. A woman, wearing an ankle length Greek dress (Ionic chiton) and a cloak (himation), with her hair tied up in a hair net/something that covered hair (sakkos), seated in a high-backed chair (klismos) facing left, resting her feet on a foot stool. She is handing over a child to another woman who stands to the left. She is bending forward with arms extended to pick the child up. This second woman is wearing an Ionic chiton and simple tunic (a shirt like Greek dress) with long sleeves, of Thracian style. Behind her appears a clearly represented loom (CVA Robinson, 32). The loom helps us to identify the setting of the scene as within the gunaikonitis. Apart from the loom there is a wreath hanging in the background almost in the centre of the vase above the space between the heads of the mother and the child. At the right of the seated figure stands a young man sporting slight whiskers on his cheek wearing a himation and leaning on a staff which he holds in his right hand.

D. M. Robinson and S. E. Freeman (CVA Robinson 32) confidently identify the young man in the scene as the father and recognise the bands in the dress of the standing woman as an indication of slavery ( $C V A$ Robinson 31-32). N. Massar (1995, 23-38), J. Neils and J. H. Oakely (2003, 230), and L. A. Beaumont $(2003,72)$ too believe that the scene depicts parents and their son with a maid servant. Judging from the wreath shown in the background, J. Neils, Oakely and L. Beaumont further clarify the scene to represent new parents with their first child. R. F. Sutton Jr. $(1981,2004)$ too continues to believe that the scene represents a nuclear family with a maid.

The owner of this particular vase may also have received it, originally, as a wedding present ${ }^{12}$ with an emblem of the family she was expected

Baltimore, MD. Fasc.2, [henceforth abbreviated as CVA Robinson 2] Cambridge, Mass., 1937, plate 43, text p. 31-32.

${ }^{10}$ A painter born in Thasos, Thrace in 500BC, who worked and died in Athens in 440BC. He was also known for his monumental wall paintings in severely classical style. The style of Polygnotos is seen in the contemporary vase paintings in Athens; he was known for his depictions of daily life.

${ }^{11}$ Fogg Art Museum, Harvard University Collection, hydria. Photo from Robinson. 
to create soon. ${ }^{13}$ Thus, the vase represents a nuclear family in the gunaikonitis who receive the assistance of a maid servant to raise their child. The wreath in the background may have been included mainly to serve two purposes: to signpost that this is a newly wedded couple and that the scene refers to the birth of their son. The scene in the vase may perhaps be intended to alleviate any fears ${ }^{14}$ that the bride may be harbouring in her mind as she enters the new household. The presence of the husband in the scene may also provide an affectionate connotation to the new bride (recipient of the ceramic gift). By presenting the husband beardless the artist is perhaps trying to make him more amicable to the young wife. In short, this vase may have been used as a sign of good omen to the young bride.

But not everyone was ready to recognize the beardless youth as the father of this child. D. Williams $(1983,94)$ thinks that the youthful figure in the vase represents the eldest son of this elite woman and points out that the 'vase painters were never very precise in their depiction of age'. Sparks (1996, 138-139) too identifies the youth in this hydria as an 'older child (or a brother -surely too young to be the husband, he has no beard)'. Moreover Clairmont $(1993,25)$ was not convinced that the Greek bridegrooms were represented in vases as pervasive beardless youths. But, as stated above, such interpretations of the youth may have had something to do with the influence of Hesiod, Plato, Aristotle and Xenophon who describe the husband or the groom as twice as old as the bride. What Sutton has to say about the youthful males depicted in wedding scenes clarifies the difference in appearance between the grooms described by Classical writers (mature adults in their 30s) and their depictions in vases (beardless youths). $\mathrm{He}$ maintains that, the vase painters depict the couple as young and beautiful embodiments of the classical ideal in order to create a romantic atmosphere at the wedding rituals for which their wares were purchased and displayed. It is, therefore, not surprising that, in depicting the oikos (household), vase painters usually show the kyrios (master of the household, generally the husband) beardless as the bridegroom (Sutton, Jr. 329).

Yet, Demosthenes reports that at least one man was prompted by his father to marry at an early age- - eighteen--because of the latter's anxiety to see grandchildren (Dem. 40.12). This raises the issue whether one should draw conclusions from isolated cases and from law-court speeches which generally exaggerate or gloss over the reality as their objective is to convince the jury at any cost; nevertheless, as the speaker at least needs to be careful to make his case plausible to the jurors, it implies that early marriage for male citizens was not totally unknown in the ancient Athenian society. Moreover, if we were to take 45 years as the average life expectancy of the adult males in classical Athens, ${ }^{15}$ many fathers would have expressed their desire to see grand children and thus to see their genealogy perpetuated and their property to have a legitimate heir. ${ }^{16}$ Moreover,

\footnotetext{
${ }^{12}$ Oakley and Sinos, p.40 figs. 124-127: shows a lebes gamikos which shows a wedding scene where many participants carry presents to the bride; some of the presents are decorated vases.

${ }^{13}$ When she died this may have been buried with her since this was unearthed from a cemetery. The half-finished work in the loom may, in the second context-grave-signify her early death. In the same way, since the textile in the loom is half finished, her life may have ended early.

${ }^{14}$ The bride's fear at entering a new household and fears of child bearing at a time when there was a high mortality rate at delivery and post-natal sicknesses.

${ }^{15}$ For discussions on life expectancy in ancient Athens cf. Sallares 107-129; Gallant 19-20, 29-30; Cox 1998.

${ }^{16}$ For a discussion on marriageable age see Golden 316-331, especially 322-323 and Roy 1-18, especially 6-9 and note 43 .
} 
many young men would marry soon before (when 18-20 years old) or sometime after (when they were around 20-25 years) they were to engage in full military service for the city (Murray 43). Despite this, some may have waited until they were 30 years or even later, depending on their circumstances, to get married.

Furthermore, it is also not improbable to state that when the vase painters began to decorate their vases with scenes from daily life they depicted what they saw in their contemporary society and not the ideal perceptions of the normative writers. As a result they depicted wedding scenes with both beardless as well as bearded bride grooms as can be seen in the following images.
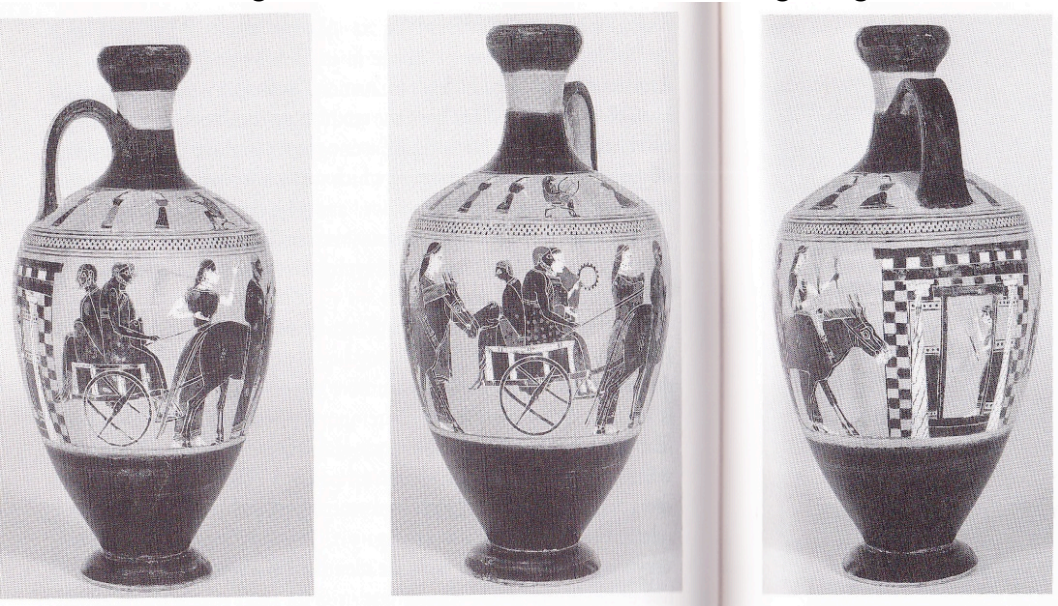

Fig.2: Wedding procession with a bearded groom, Amasis painter (Boardman fig. 38)

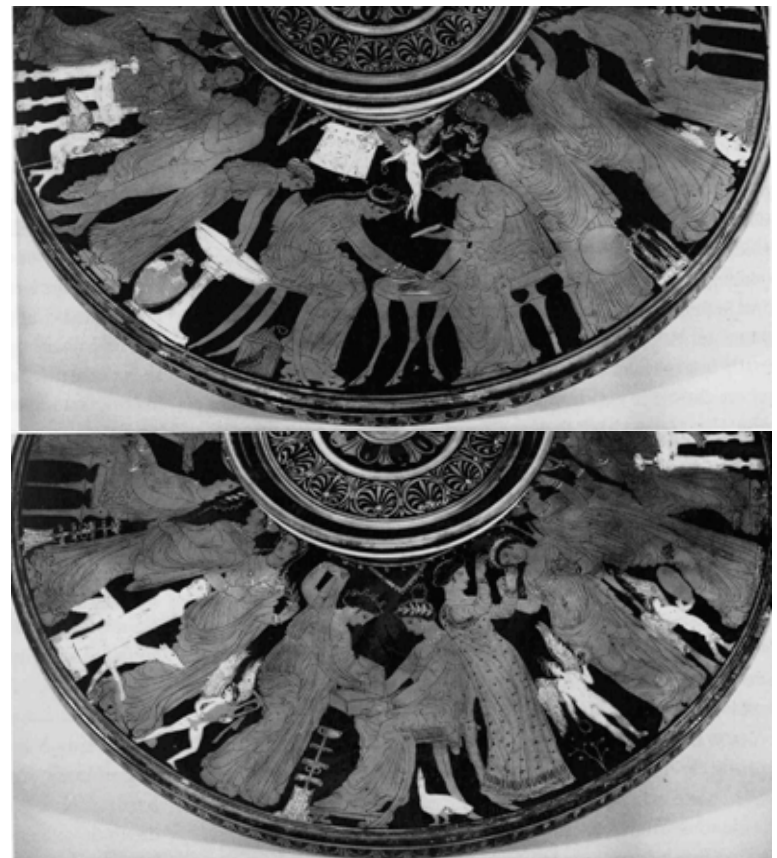

Fig.3: Wedding preparations including Bride, Bridesmaid, Mother and Beardless Groom (Niels, Oakley fig. $18 \mathrm{a}, \mathrm{b})$. 
Accordingly, family scenes with both bearded and beardless husbands/fathers may have been painted as appropriate. The following vase shows a secular family with a bearded husband/father. However, following Xenophon's perception, scholars are hesitant to recognize the bearded gentleman as the father of the child or the husband of the woman shown; instead they identify him either as the grandfather or the caretaker (paidegogos) of the child. This idea again seems to be dominated by the idiosyncratic conceptions fuelled by Xenophon which considered it disgraceful for a man to spend time indoors in the gynaikonitis during the day. ${ }^{17}$ Accordingly, men were generally shown engaged in outdoor activities (commonly considered as the male sphere of life) centred on the exercising place (gymnasion), wrestling school (palaistra) or in the market place (agora) if not in the farm or field, while dignified women were shown within the gynaikonitis attending to womanly chores.

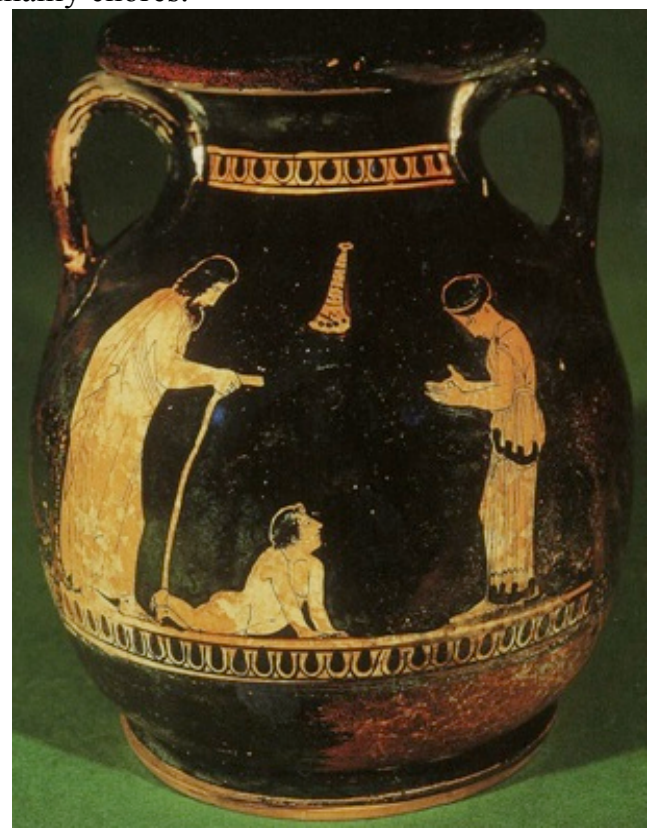

Fig.4: An Attic red-figure pelike, showing a baby learning to crawl or walk ${ }^{18}$

The following scene which mirrors another scene from a domestic setting including a nuclear family, i.e. husband, wife and a child with a nurse/maid, also paints the husband with a full beard. A wool basket (kalathos) placed to the extreme right side of the scene indicates that this happens within a gunaikonitis. Yet none of these scenes provide any indication of time. We could, thus, safely suggest that the scenes represent an event that occurred towards the end of the day after the husbands had returned home to their families.

\footnotetext{
${ }^{17}$ See foot note 4 .

${ }^{18}$ This was attributed to the manner of the Washing painter, ca. 430-420 BC London, The British Museum. Niels, Oakley, 2003, catalogue number 37.
} 


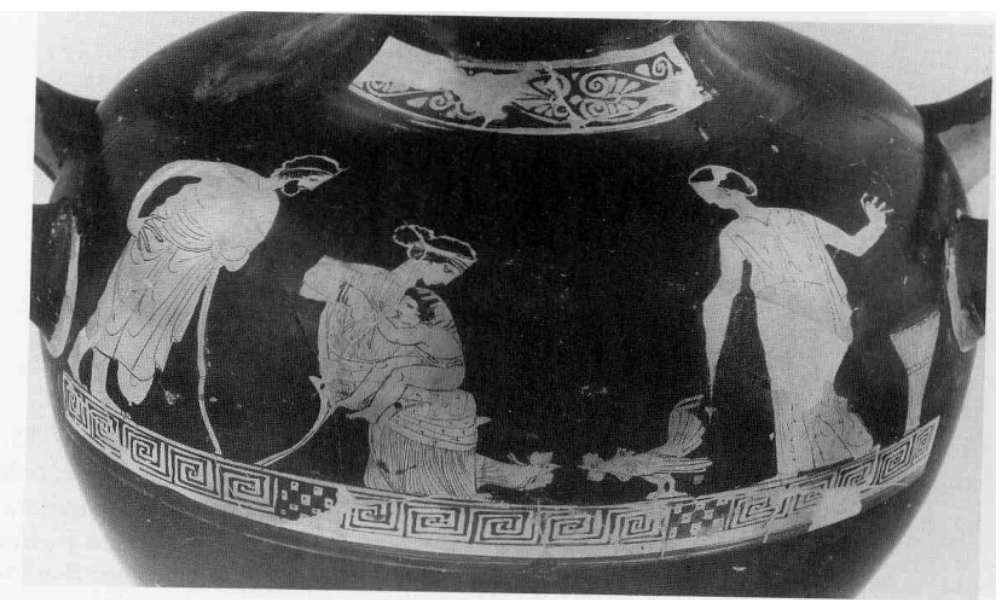

Fig.5: A family scene in an Attic hydria vase (Sutton, Jr., 1981 figs. 17.14)

Moreover, the message transmitted through the inclusion of cocks in this scene in the gunaikonitis may be twofold, as this bird symbolizes both affection (erotism) and masculinity (Hoffmann 148). Accordingly, it may firstly indicate that close male relatives (such as the husband) are permitted within the gunaikonitis and, secondly, the presence of sentiments such as affection within it.

The following vase (fig. 6) also presents a nuclear family almost similar to the one we saw at the beginning (fig. 1), beardless husband, wife, and child with a maid. The noticeable differences here are that the child is older than the one in the former vase painting (fig. 1) and the husband and wife are positioned facing each other, although the wife avoids the gaze of the husband and is busy with her distaff and wool-work perhaps in a hurry to finish the work or intending to stop at a point to attend to the husband.

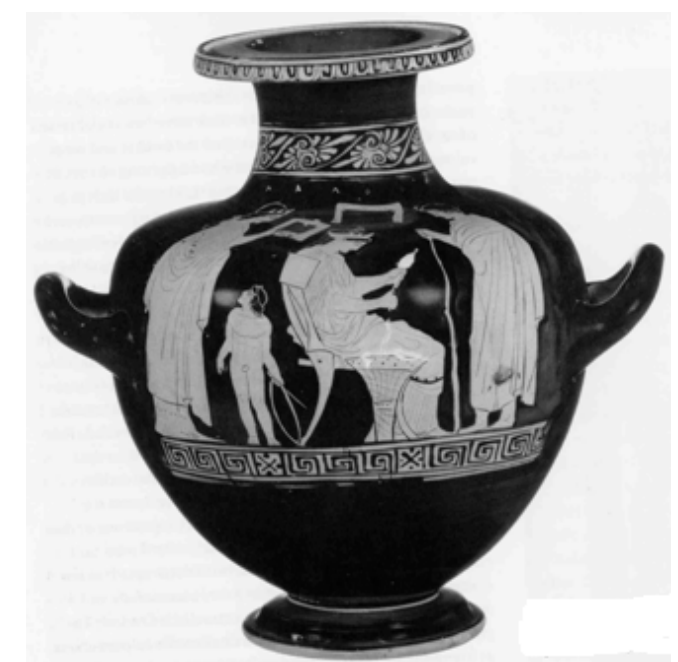

Fig.6: A family group in an Attic red-figure kalpis/hydria (Neils, Oakley fig. 12) ${ }^{19}$

\footnotetext{
${ }^{19}$ This was attributed to an artist close to the Clio painter, third quarter of the fifth century BC, Munich.
} 
The following pyxis vase (fig. 7) too contains a family scene, but this time with more members, while the husband is not depicted as a passive observer. He is shown offering a fruit or some such object to the seated and veiled wife who is busy working wool. The husband here is beardless and the maids are helping her both to nurture her children and to work the wool. The spouses do not face each other as in fig.6, but are positioned as in the Harvard hydria (fig.1); however, there is hope that this arrested motion could change at any time.

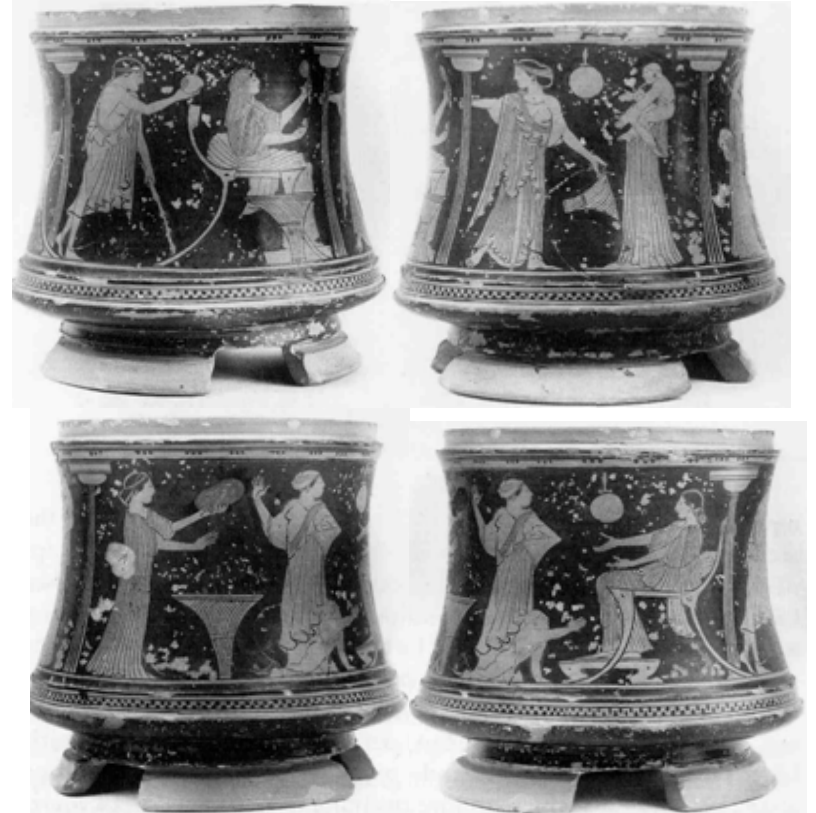

Fig.7: Family group shown around a pyxis vase (Sutton, Jr. Figs, 17.13).

As in the previous scenes, the husbands in these scenes too may have just returned home from work/ field. Information deducible from the Athenian orators too piles up in favour of the positive attitude with regard to affection between Athenian spouses. Warm and affectionate relationship between Athenian spouses is narrated by Lysias. However, a careful observation of the very same information used by Keuls to argue that no affection existed among the Athenian spouses provides a contrary view point.

I must tell you, sirs (for I am obliged to give you these particulars), my dwelling is on two floors, the upper being equal in space to the lower, with the women's quarters above and the men's below. When the child was born to us, its mother suckled it ; and in order that, each time that it had to be washed, she might avoid the risk of descending by the stairs, I used to live above, and the women below. By this time it had become such an habitual thing that my wife would often leave me and go down to sleep with the child, so as to be able to give it the breast and stop its crying. ....

I came home unexpectedly from the country, and after dinner the child started crying in a peevish way, as the 
servant-girl was annoying it on purpose to make it so behave; for the man was in the house, - I learnt it all later. So I bade my wife go and give the child her breast, to stop its howling. At first she refused, as though delighted to see me home again after so long; but when I began to be angry and bade her go, _ - " Yes, so that you," she said," may have a try here at the little maid. Once before, too, when you were drunk, you pulled her about." At that I laughed, while she got up, went out of the room, and closed the door, feigning to make fun, and she turned the key in the lock. I, without giving a thought to the matter, or having any suspicion, went to sleep in all content after my return from the country. Towards daytime she came and opened the door (Lysias I. 9-14). ${ }^{20}$

This extract from Euphiletus suggests that, in general, men's quarters were downstairs while women's were upstairs. This action of swapping their quarters, as he claims, was to ensure the safety of his wife subsequent to the birth of the child because the water needed to wash the child was available only downstairs and the action itself implies some degree of affection towards the wife (Lysias I. 11-14). Moreover, by looking at this information alone it is hard to say that husbands and wives slept separately because in this particular context circumstances such as the presence of an infant who demands much maternal attention throughout the night, and of a husband living in the farm visiting his family at occasional intervals may any way keep the spouses apart for most of the time. On the other hand, Euphiletus himself tells us of the relationship he enjoyed with his wife: a blend of warm affection, jokes and laughter which led him to trust his wife in all her affairs until he was allegedly informed, by a maid, of the adulterous affair between his wife and Eratosthenes. Also, the information that the baby had to be artificially induced (by pinching) to cry to make the wife return to the baby (and then to her paramour) from the husband's quarters implies that she spent time in the company of the husband when he was at home even after the birth of the baby. Moreover, her reluctance to leave the company of the husband all at once to return to the baby when it was crying seemed normal to Euphiletus.

Although this information may suffer from a certain degree of exaggeration and even if he may not be presenting the real relationship with his wife (Carey 61-64), at least he paints a picture that appears normal in the eyes of the jurors, to win their favour. ${ }^{21}$ In one of the Demosthenic speeches, Apollodorus too expresses his care and concern for his wife and children although it is possible that he may be faking his care for his wife as he later accuses her, but he at least expects the jury to consider it as normal behaviour in the Athenian society (Dem. 50.62). A funeral oration attributed to Lysias [445-380] (Lysias 2. 75) provides further interesting information as to the Athenian attitude to affection for one's children and wife. To show gratitude to the dead, the author instructs the necessity to 'embrace their children (aspazoimetha) as if we were their fathers, help their

\footnotetext{
${ }^{20}$ Translated by Lamb, W. R. M., Loeb ed. Heinemann, 1930. Bold font is used here for emphasis.

${ }^{21}$ We must note that he faces a serious allegation, the murder of a citizen, which he has admitted. If he does not succeed in defending himself, he may face death; if he manages to escape, he would be exiled and all his property confiscated.
} 
wives as they did when alive.' Since funeral speeches were regarded as public announcements in ancient Greece ${ }^{22}$, because they were delivered at public gatherings to ensure the safety of the widows, such thoughts could be considered as the accepted values of the Athenian community. Similarly, funerary reliefs (stelai), with or without inscriptions, too become public announcements/exhibits as they were open for the passing public to view and read.

Some funerary reliefs, which are shown below (figs.7 and 8), too testify to the affectionate bond that prevailed between Athenian spouses (Lacey plate 29; Blundell plate 24; Pomeroy 26-27, plate 1a esp. b). For instance, several funerary reliefs show a young wife bidding farewell to her husband probably at childbirth. These are reminiscent of the Harvard hydria, where the wife has successfully gone through the stage of child bearing. The expressions in the images of the funerary reliefs shown below, datable to $400 \mathrm{BC}$, indicate the affection they were sharing when alive and the loss felt by the living spouse due to the death of the other. If no affection existed when they were alive, will such emotions manifest themselves after death?
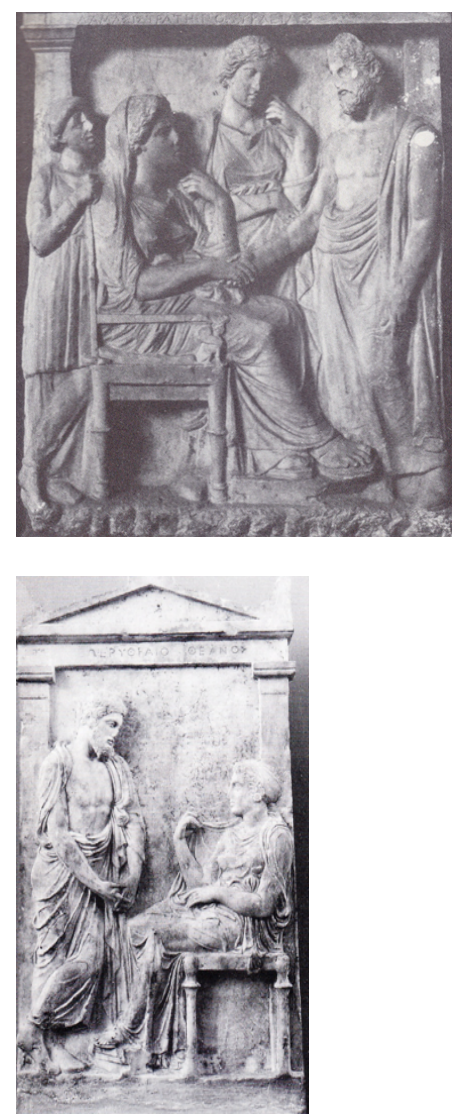

Fig.8: Damasistrate, Polycleides' wife, bids her husband farewell.

Fig.9: Grave stele of Ktesilos and Theano (Lacey plate 29) from Athens (Blundell plate 24).

\footnotetext{
${ }^{22}$ Especially as in this case where the men have died at a common cause fighting for the country against the Persians.
} 
Furthermore, the absence of large beds in iconographic representations, which Keuls cited as proof to show less affection between Athenian spouses, may not constitute strong evidence as Greek vase painters only depicted the items that were indispensable to understanding a scene in the background of their respective paintings. For instance, when they needed to indicate an outdoor scene they would do so by drawing a tree in the form of a stiff twig or by showing a stone and/or a bird as can be seen in figs. 10 and 11 respectively. Thus, showing something which resembles a narrow bed could be interpreted as one form of artistic license, one way of overcoming the restrictions of the artist's medium in representing his scenes as it is hard to expect detailed drawings of household items in iconographic representations.

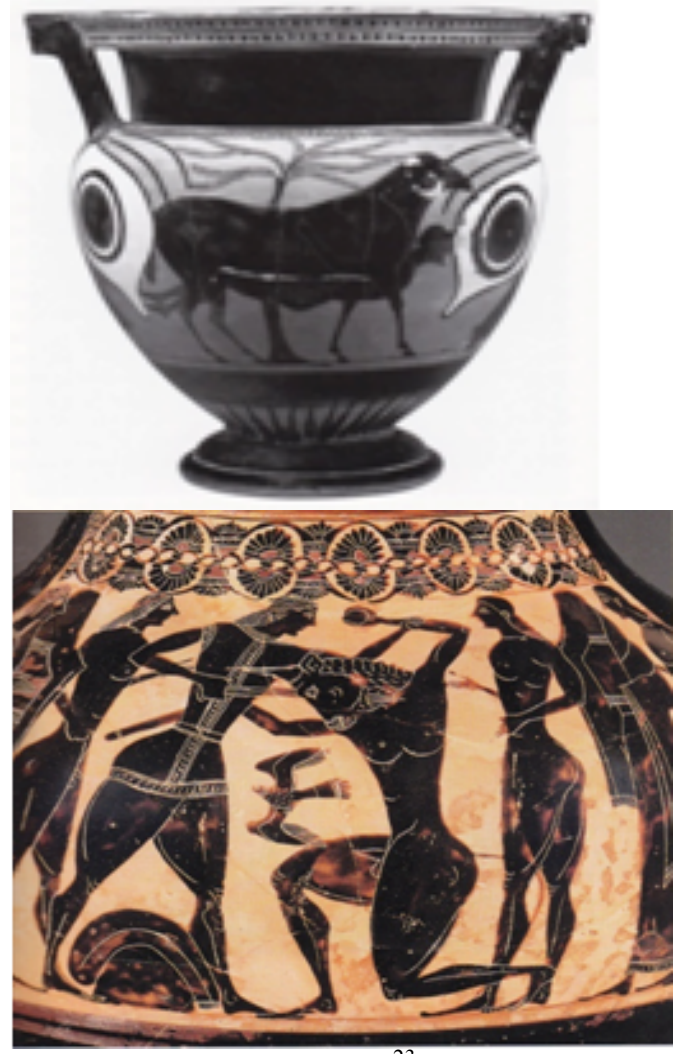

Fig. 10: Odysseus escaping the Cyclops' cave $\mathrm{e}^{23}$

Fig.11: Theseus killing the Minotaur (Clark 37) ${ }^{24}$ (Clark fig. 98)

Giving away the child to a nurse as shown in the Harvard hydria may also hint at the affectionate care a wife harbours towards her husband in return for his. It reminds us of the analogous setting described by Euphiletus in his house. This action of the young wife handing-over the child to a nurse can, therefore, be interpreted as the wife's readiness to welcome and to attend to the needs of the

\footnotetext{
${ }^{23}$ A column krater dated to 550-500 B.C. by an unidentified artist.

${ }^{24}$ 'A type' black figure panel amphora by Lydos painter (550- 540 B.C.).
} 
husband who, perhaps, has just returned home. ${ }^{25}$ The male ideology which, apparently, considered it shameful to see the husband inside the house $\mathrm{s}^{26}$ during the day may have prompted Athenian artists to present the husband and wife busy in their own spheres of life separated from each other. Also, as noted above, none of these domestic scenes provide us any indication of time. The scene on the Harvard hydria and the other parallel scenes on vases as presented above in this study could, therefore, be a few of the rare productions where the artist has allowed a quick glimpse of the real situation. The artist's prudence to depict the reality without completely disrupting the rude male idiosyncratic standpoint which does not provide space for any affection between Athenian spouses is implied by signalling that the male figure has just entered the house and by positioning the wife with her back towards the husband or by simply avoiding each other's gaze. Athenians who were familiar with normal family ambiance would imagine the next action of these individuals as appropriate: a wife's readiness to greet her husband. Besides, if the bride-recipient of the Harvard hydria vase was not familiar with such scenes in her society, the vase would fail to fulfil its intended purpose, which is to alleviate the fear of the bride when merging into a new family, and to encourage her by showing her the comfort of an affectionate relationship with her husband. Also, the onlookers of the other vases, which are either pelike, pyxis, kalpis or hydria vases that were mostly used by women but perhaps mostly bought by men, were familiar with such scenes in their own domestic spheres.

Having thus examined iconographic representations and evidence from orators in this regard, we next focus on poetic compositions and dramatic performances to examine whether they reveal or hint at affectionate liaisons between spouses, which may influence the Athenian society. Genuine affection between spouses can be seen between Hector and Andromache in the Iliad (6.429$32,490-493 ; 24.742-745)$ and between Penelope and Odysseus in the Odyssey (19. 109-111, 127-161; 23. 233-240). Though Homeric epics fall into a time much before the classical period, they were part and parcel of the Greek curriculum and the anecdotes and incidents in them were familiar to and influenced the Greeks of all times. In fact, one of the concerns of Plato in eliminating bad passages from these texts was due to the strong influence the Homeric and Hesiodic texts cast upon his fellow Greeks. On the other hand, if one considers these relationships to be mythical, one must also remember that myths show what the Greeks wanted to accept or believe; in other words, they show how the people's minds work.

As for the rarity of such scenes depicted in literary or iconographic sources, one must remember that the ideal representations of Aeschylus and Sophocles allowed no space for representing the real happenings of society. Most such conservative writers wanted to preserve the expected norms of the society, which was constantly at war with the neighbours, to guard their safety and exhibit their power over the weaker states. Thus, when a military career was elucidated, they generally tried to gloss over the normal sentiments shared by the spouses. Nonetheless, snippets from the classical Athenian society also occur in

\footnotetext{
${ }^{25}$ Some scholars such as Stone, L., The Family, Sex and Marriage in England, 1500-1800, London, 1977, pp. 651-652 may find in such an event an attempt to keep a distance between the child and its parents in society with a high infant mortality rate, so that they would be more accustomed to face the death of a child if that occurred. See also Golden 1990, 82-83. But the affection between children and their parents in some reported cases makes it hard to conclude that handing over a child to a nurse was always practiced as a means of getting parents accustomed to bear the loneliness if they were to lose a child.

${ }^{26}$ By judging from the rarity of such scenes in iconographic illustrations.
} 
dramatic performances which were intended to entertain the contemporary as well as subsequent societies.

The dramatic representations of the revolutionary Athenian tragedian Euripides [480-406 BC] and some productions of Aristophanes and later comedians seem to bring forth or at least hint at the realistic features of their contemporary Athenian society. Euripides' Medea is a fine illustration of the conflict between what men believed about marriage and relationship between spouses, and the reactions of women. For instance, although Euripides is determined to present the real social set up, he could not fully dislodge the deep rooted male attitudes on marital relationships. Thus, he inculcates the view that 'marriage is a woman's saving point and all she needs to do is to be obedient to her husband's will in all occasions' (lines 13-14). He further expresses that the wife should not react badly or be moved if the husband is won to a new love (lines 154155). Yet, Euripides at the same time understands Media's grief and shows through the words of the nurse that not all women are ready to tolerate passively such dispositions of their husbands (lines, 19-43, 83-84, 112-114, and 208). Her grief is acutely felt perhaps because she had experienced an affectionate relationship with her husband Jason at least before this tragedy has struck her family. Thus, Medea's love for Jason has transformed into hatred through the intense grief she experienced when Jason betrayed, as she seems to have believed, the much expected and valued marital affection and confidence.

Moreover, in Euripides' Helen, Menelaus is depicted as a loyal husband to his wife Helen, even when the real Helen explains to him that it was her phantom he is guarding in a cave in Egypt where he was shipwrecked (lines 577593). Although this could be the author's fabrication to suit his plot, Euripides' attempt to make Menelaus reject the woman who resembled very much the appearance of Helen, even when that woman claimed to be his wife, is very significant. He emphatically says that he cannot take her because he already has a wife which indicates his loyalty to his wedded spouse. We must note here that Menelaus takes this decision independently and no oath bound him to act so. Furthermore, the affectionate relationship between Helen and Menelaus is clearly illustrated through the lines 619-645 when Menelaus realises that it was the real Helen he met and conversed with in Egypt. Despite poetic license, Euripides may have embedded the current social disposition in his characters, so that the audience could identify themselves with these characters and scenes. Thus, the affectionate bond between spouses projected by Euripides may not have been a pure invention.

Furthermore, with regard to Greek comedy, the sex strike and the subsequent events presented in Aristophanes' [448-380 BC] Lysistrata may not only be pointing at the sexual indulgence of men, but hinting at the amicable and affectionate bond between these spouses. Moreover, Terence's [185-159 B.C] plays such as Hecyra (Mother-in-law), which were adaptations of Greek models mostly taken from Menander[(342-291 B.C] who either refers to the classical or his contemporary Athenian society, too provide vital information on Athenian marital life. For instance, in Hecyra (Mother-in-law) the young husband (Pamphilus) started loving his wife when she bore with his harsh manners. His affection to the wife is displayed through his act of rushing into the gunaikonitis when he heard her painful cries on his return from a long journey (lines 315-332). This play may be presenting a banal incident in the classical or fourth century Athenian society that testifies to the existence of affectionate relationships between Athenian spouses due to the very reason that this detail was not intended to generate humour. 
To sum up, a close look at some of the evidence which can be construed, for instance, from law court speeches, literary texts and scenes from iconographic representations provide us a window to the Athenian family which is different from the cold mechanical bond between Athenian spouses as given by the writers of normative texts. The insight we are provided through a meticulous study of our literary sources and vase paintings is that despite traditional perceptions there existed positive sentiments such as warm and genuine affection between Athenian spouses in antiquity. Yet, we must also remember that the disposition of each family may have been unique to its own private setting and what a family expected the wider community to know of the relations among its members could have been different to the real situation. The cold relationship often depicted to have existed between Athenian spouses and the introduction of the wife as an agent of procreation may have been regulated by the masculist ideology of the normative writers and by the extremists that dominated the Athenian society. The isolated instances we see as different to what is generally recorded or presented within the framework of male viewpoints could be a glimpse of the private moments of a family which filtered into the wider pool of information unbeknownst to the writers, artists ${ }^{27}$ and even the individuals themselves. The Harvard hydria and other parallel iconographic representations presented in this study, therefore, offer us a few rare glimpses into the private sphere of the ancient Athenian households.

\section{Works Cited}

Beaumont, L., 'The changing face of childhood' p. 72 in Coming of Age in Ancient Greece: Images of Childhood from the Classical Past, exhibition 20032004, Hanover, J. Neils and J. H. Oakely edds,. New Haven and London, 2003.

Blundell, S., Women in Ancient Greece, Cambridge and Mass. 1995.

Boardman, J., Athenian Black Figure Vase Painters, A Handbook, London, 1991.

Carey, C., Lysias: Selected Speeches, Cambridge, 1989.

Clairmont, C. W., Classical Attic Tombstones, Kilchberg, 1993, introductory volume.

Clark, A. J., Elsten, M., Heart, M. L., Understanding Greek Vases" A Guide to Terms, Styles and Techniques, Los Angeles, 2002.

Cox, C. A., Household Interests: property, marriage strategies and family Dinamics in Ancient Athens, Princeton, 1998.

Gallant, T. W., Risk and Survival in Ancient Greece, 1991.

Golden, M., 'Demography and the exposure of girls' Phoenix, vol. 35, 1981.

Golden, M., Children and Childhood in Classical Athens, Baltimore and London, 1990.

Harrison, A. R. W., The Law of Athens, vol. 1, new ed. London and Indiana, 1998.

Hoffmann, H., 'Why did the Greeks need imagery? An anthropological approach to the study of Greek vase painting,' Hephaistos, vol. 9, 1988.

Keuls, E. C., The reign of Phallus: sexual politics in ancient Athens, London, 1993.

Lacey, W. K., The Family in Classical Greece, Ithaca, New York, 1968.

Lamb, W. R. M., tr. Lysias Loeb ed. Heinemann,1930.

\footnotetext{
${ }^{27}$ See Sutton (Jr.), 1981, for a few more private moments of a family; Sutton (Jr.), 2004, 327-350. Also see, Roberts, 1978, which also contain many illustrations of pyxis vases with similar domestic scenes.
} 
Massar, N., 'Image de la famille sur les vases Attiques à figures rouges à l'époque classique (480-430 av. J.C) in Annales D'histoire de l'art et archaeology, Free University of Brussels, vol. 17, 1995.

Murray, G., Euripides and his Age, London, 1913.

Neils, J., and Oakely, J. H., eds. Coming of Age in Ancient Greece: Images of Childhood from the Classical Past, exhibition 2003-2004, Hanover, New Haven and London, 2003.

Oakley, J. H., and Sinos, R. H., The Wedding in Ancient Athens, Madison, 1993.

Pomeroy, S.B., Families in Classical and Hellenistic Greece: Representations and Realities, Oxford, 1997.

Roberts, S., The Attic pyxis, Chicago, 1978.

Robinson, D. M., Corpus Vasorum Antiquorum, United States of America, The Robinson Collection, Baltimore, MD. Fasc.2, [ abbreviated as CVA Robinson 2] Cambridge, Mass., 1937.

Roy, J., 'Polis and Oikos in Classical Athens' Greece and Rome, vol. 46.1, 1999.

Sallares, R., The Ecology of the Ancient World, London, 1991.

Sparks, B., The Red and the Black: Studies in the Greek Pottery, London, 1996.

Stone, L., The Family, Sex and marriage in England, 1500-1800, London, 1977.

Sutton Jr., R. F., 'Interaction between men and women in Attic red-figure pottery' Dissertation submitted to the university of North Carolina in Chapel Hill for the degree of Master of Philosophy, 1981.

Sutton Jr., R. F., 'Family portraits: recognizing the oikos on Attic red-figure pottery' in Charis: Essays in honour of Sara A. Immerwahr, ed. by A. P. Chaplain, Hesperia Supplement vol. 33, 2004, pp. 327-350.

Williams, D., 'Women on Athenian vases: problems of interpretation', in Images of Women in Antiquity, Cameron, A, and Kuhrt, A., London and Canberra, 1983.

Chandima S.M. Wickramasinghe, University of Peradeniya, Sri Lanka 